\title{
PRIBUMISASI ISLAM NUSANTARA: ANTARA NALAR BERAGAMA DAN GERAKAN SOSIAL KEAGAMAAN DI INDONESIA
}

\author{
Arik Dwijayanto \\ Fakultas Dakwah IAI Sunan Giri Ponorogo \\ arikdj99@gmail.com
}

\begin{abstract}
This study aims to explore the values of Islamic Nusantara as the reason of religiousity and spirit of religious-social movement in Indonesia. Islam Nusantara in its development comes as social-religious movement for moderate society to maintain the existence of tolerant Islamic teachings. Through the historicalsociological approach, the results of this research show the fact that there are four factors that encourage the indigenous Islamic Nusantara emerged as a social movement in Indonesia. Firstly, the historical fact of the santri-kyai's contribution through the Jihad Revolution in defending independence has reinforced that there is no dichotomy between religious teachings and nationalism. Secondly, as a result of the internalization of the value of character education through "pesantren" and "madrasah" that has proven to be a stronghold in the face of religious radicalism. Thirdly, as a continuation of the ideas of the predecessors (moslem scholars) to present a friendly, tolerant and peaceful of Islamic doctrine. Fourthly, as the realization of the responsibility of religious organizations that rely on the understanding of Islamic teachings based the value of Ahlussunnah waljamaah.
\end{abstract}

Keywords: Islam Nusantara, Moderate, Religious and Social Movement

\begin{abstract}
Abstrak
Artikel ini bertujuan untuk mengeksplorasi nilai-nilai Islam Nusantara sebagai nalar beragama dan basis spirit gerakan sosial-keagamaan di Indonesia. Islam Nusantara pada perkembangannya hadir sebagai gerakan sosial-keagamaan kaum moderat untuk menjaga keberadaan ajaran Islam yang toleran. Melalui pendekatan historis-sosiologis, hasil penelitian ini menunjukkan gambaran bahwa terdapat empat faktor yang mendorong pribumisasi Islam Nusantara muncul sebagai suatu gerakan sosial-kegamaaan di Indonesia. Pertama, modal historis atas kontribusi santri-kyai melalui resolusi Jihad dalam mempertahankan kemerdekaan telah menguatkan pemahaman bahwa tidak ada dikotomi antara ajaran agama dan nasionalisme. Kedua, sebagai hasil dari internalisasi nilai pendidikan karakter melalui pesantren dan madrasah yang telah terbukti mampu menjadi benteng dalam menghadapi radikalisme keagamaan. Ketiga, sebagai kesinambungan dari eskavasi gagasan-gagasan para pendahulu untuk menghadirkan wajah Islam yang
\end{abstract}


Arik Dwijayanto, Pribumisasi Islam Nusantara...

ramah, toleran dan damai. Keempat, sebagai realisasi dari tanggung jawab organisasi keagamaan yang bertumpu kepada pemahaman ajaran Islam Ahlussunnah waljamaah.

Kata Kunci: Islam Nusantara, Moderat, Gerakan Sosial-Keagamaan

\section{Pendahuluan}

Istilah Nusantara dalam konteks peradaban Islam digunakan untuk menyebut kawasan yang meliputi wilayah-wilayah Islam di Asia Tenggara seperti Indonesia, Malaysia, Selatan Filipina, Brunei dan Selatan Thailand. ${ }^{1}$ Kehadiran Islam di Nusantara mempunyai sejarah yang unik dan menarik. ${ }^{2}$ Islam hadir di

\footnotetext{
${ }^{1}$ Nusantara merupakan kawasan geopolitik strategis bagi lalu lintas perdagangan dan pelayaran. Misalnya, Selat Melaka menjadi pintu masuknya kapal-kapal dari luar Nusantara yang menghubungkan antara Laut Hindia denga Laut China Selatan. Melalui Melaka, hasil hutan dan rempah-rempah dari berbagai kepulauan di Nusantara dibawa ke China, India dan Timur Tengah. Nusantara juga bukan hanya dikenal sebagai pusat perdagangan tetapi sebagai tempat pertemuan berbagai kebudayaan dan kepercayaan. Lebih lanjut baca, Muhammad Yusoff Hashim, Pensejarahan Melayu Nusantara, Kuala Lumpur: TP Teks Publishing, 1988, 1, Mahayudin Haji Yahya, Islam di Alam Melayu, Kuala Lumpur: Dewan Bahasa dan Pustaka, 1998, 4, Badri Yatim, Sejarah Peradaban Islam, Jakarta: Rajawali Press, 1993, 192.

${ }^{2}$ Unik dan menarik mengingat agama Islam tidak dilahirkan di gugusan kepulauan Nusantara, tapi justru di kawasan inilah terdapat penduduk muslim dengan jumlah terbesar di dunia. Proses masuknya Islam di Nusantara juga memunculkan beragam versi yang berbeda. Diantaranya Marcopolo dalam laporannya mengenai Sumatra (sekitar 1292) menyebut komunitas Muslim baru didirikan oleh para pedagang "Moor" di Perlak. Salah satu bukti yakni terdapat batu nisan seorang muslim yang disebut Malik al-Shalih sebagai penguasa di Samudra Pasai. Lain lagi dengan pendapat Thomas W. Arnold, yang menyatakan Islam datang ke Nusantara pada abad ke 7 M yang dibawa oleh para saudagar Arab. Berbeda dengan tulisan mistikus kelahiran Aden, Abdallah b. As'ad al Yafii (1298-1367) yang menyebutkan bahwa penyebaran Islam ke Nusantara dijalankan oleh para syaikh tarekat. Lebih lengkapnya baca karya Michael Laffan, Sejarah Islam di Nusantara, Yogyakarta: Bentang Pustaka, 2015, 3-5. Sedangkan menurut pandangan Snouck Hurgronje (1857-1936), seorang orientalis Belanda, muslim pura-pura dan bagian dari rezim kolonial menyebut bahwa pada abad ke-13 Masehi merupakan permulaan masuknya Islam ke Nusantara melalui Persi dan Gujarat. Ada pula pendapat yang kontroversial dari Tome Pires dalam karyanya Suma Oriental menyatakan bahwa kehadiran para pendatang yang membawa Islam ke Nusantara tidak selalu dengan jalan damai. Pires mengatakan : "Sejumlah orang Moor (kaum Muslim di Andalus) membangun benteng disekeliling tempat mereka tinggal, mengirimkan kaumnya sendiri untuk berdagang, membunuh penguasa Jawa kemudian mengangkat dirinya sebagai penguasa yang baru. Dengan demikian, mereka berhasil menjadikan diri mereka sebagai penguasa dan mengambil alih perdagangan serta kekuasaan di Jawa. "Baca Tome Pires, Suma Oriental: Perjalanan dari Laut Merah ke Cina \& Buku Fransisco Rodrigues, Yogyakarta: Penerbit Ombak, 2014, 255. Pernyataan Pires yang kontroversial tidak banyak dijadikan rujukan sejarah bahkan dengan sendirinya tertolak dengan beragam pendapat yang mengamini bahwa masuknya Islam ke Nusantara melalui pendekatan yang damai dan santun sebagaimana telah diulas secara jelas oleh Sejarawan Islam Agus Sunyoto dalam karyanya Atlas Walisongo. Dalam bukunya dipaparkan bahwa selama kurun waktu 50 tahun khususnya di tanah Jawa ketika para Wali Songo menyampaikan ajaran Islam, masyarakat di sepanjang pesisir utara pulau Jawa memeluk Islam tanpa pertumpahan darah. Kecepatan adaptasi para wali dengan kultur masyarakat
} 
Nusantara dalam situasi persaingan agama dan kebudayaan. Sepanjang abad ke-13 sampai ke-16 Masehi, Islam berkembang pesat di seluruh gugusan kepulauan Nusantara. Islam menyatu dengan kebudayaan yang kemudian menjadi ciri khas dari karakter keagamaan bangsa-bangsa di Nusantara. Proses Islamisasi hadir tanpa ada paksaan untuk meninggalkan budaya masyarakat lokal yang sudah mengakar sebelumnya. Sebagaimana masyarakat Jawa yang tidak merasa dipaksa untuk membuang budaya warisan Hindu-Budha-Kejawen dalam menerima Islam sebagai kepercayaan. Demikian juga masyarakat Minangkabau juga tidak dipaksa untuk meninggalkan budaya adat perpatih mereka. Pola Islamisasi ini menjadi pertemuan antara nilai-nilai universal Islam dengan nilai-nilai budaya pribumi sehingga melahirkan karakteristik Islam yang khas yakni Islam Nusantara. ${ }^{3}$

Islam Nusantara dalam kajian ini merujuk pada kawasan Indonesia sebagai basis masyarakat Muslim terbesar di Asia Tenggara. Dalam diskursus keagamaan di Indonesia, terma Islam Nusantara mengalami distorsi pemahaman mengingat dianggap sebagai representasi organisasi keagamaan tertentu. Tulisan ini hendak memperlihatkan sejauhmana Islam Nusantara secara konseptual tidak hanya menjadi nalar beragama tetapi juga spirit gerakan sosial-keagamaan sebagai ikhtiar dalam mengawal moderatisme Islam di Indonesia.

\section{Genealogi Islam Nusantara}

Gagasan Islam Nusantara menguat dan menemukan momentumnya ketika muktamar Nahdlatul Ulama (NU) pada tahun 2015 di Jombang. Namun jauh sebelumnya gagasan yang serupa pernah dilontarkan oleh Abdurrahman Wahid (Gus Dur) pada era 1980-an melalui gagasan pribumisasi Islam. Tentu saja, istilah

\footnotetext{
lokal menjadi salah satu kunci islamisasi khususnya di Pulau Jawa. Para wali yang datang ke Nusantara tidak memaksakan budaya Arab-Persia untuk diterapkan di masyarakat. Ajaran Islam yang diutamakan adalah akhlak (moralitas) yang merupakan bagian dari ajaran Islam yang rahmatan lil 'alamin. Begitu juga para wali tidak membid'ahkan, mengkhurafatkan, apalagi mengkafirkan budaya maupun tradisi masyarakat. Penghargaan atas perbedaan kultur/budaya masyarakat setempat dengan menggunakan pendekatan kearifan lokal, ajaran Islam dapat diterima secara massal di Nusantara. Lebih lanjut baca Agus Sunyoto, Atlas Walisongo, Bandung: Mizan, 2012.

${ }^{3}$ Siddiq Fadzil, "Pertembungan Islam dengan Budaya Peribumi: Pengalaman Alam Melayu”, Kertas Kerja Seminar Hukum Islam Semasa III, Akademi Pengajian Islam , Universiti Malaya, 2000, 1-2.
} 
Arik Dwijayanto, Pribumisasi Islam Nusantara...

pribumisasi secara praksis jauh lebih tua. Dakwah Walisongo di pulau Jawa misalnya, telah menggunakan kearifan-kearifan lokal dan tradisi sebagai metode. Walisongo tidak seluruhnya menghapus tradisi-tradisi lokal dan menggantinya dengan Islam. Walisongo mempertahankan segi-segi tradisi dan mencoba mengadaptasinya dengan ajaran Islam tanpa merusak nilai substansialnya. Salah satu contoh, bangunan masjid kuno masih mempertahankan model Hindu-Budha pada aspek kubahnya yang bersusun tiga. Pribumisasi Islam, karena itu memiliki kaitan langsung dengan sejarah perkembangan Islam di Nusantara dan telah terjadi dalam sejarah yang panjang. Pribumisasi Islam sebagai suatu proses sosio-historis merupakan sebuah keniscayaan. Hal ini demikian karena universalitas Islam memerlukan penjabaran operasional sehingga eksistensinya lebih efektif. Selanjutnya, universalitas tak akan efektif tanpa diikat oleh nilai-nilai lokal. Agar universalitas Islam terasa hadir dan relevan dengan gemuruh kehidupan sosial di bumi, ia perlu diturunkan ke tingkat abstraksi yang sederhana; yang mudah dimengerti oleh akal; dan agar menjadi pedoman hidup praksis bagi manusia. Dari argumen inilah, pribumisasi Islam menemukan maknanya. ${ }^{4}$

Menurut Gus Dur agama selain memiliki dimensi keimanan dan keTuhanan yang sakral dan mutlak, juga memiliki dimensi kebudayaan/kultural yang melahirkan berbagai simbol dan ritus.dimensi sini sangat sulit untuk dirumuskan, mengingat masih simpang-siurnya pengertian dan luas lingkup kata "budaya" itu sendiri. Pandangan Gus Dur ini menyiratkan bahwa meski agama mengandung ajaran tunggal, namun dia dipahami oleh umat umat yang memiliki latar belakang pengetahuan, pengalaman, dan kepentingan yang berbeda dan plural. Di samping itu tidak semua simbol dan ritus itu sebagai sesuatu yang baku yang bisa dianggap sebagai ajaran yang harus dijaga dan dipertahankan. Di dalam agama ada dimensi kebudayaan yang kadang juga menjelma dalam bentuk simbol dan ritus. Sebenarnya umat beragama memilki kebebasan untuk mengubah simbol dan ritus yang menjadi bagian dari

${ }^{4}$ Mudhofir Abdullah, "Pribumisasi Islam dalam Konteks Budaya Jawa dan Integrasi Bangsa”, Makalah yang disampaikan dalam Dies Natalis XXI IAIN Surakarta, 9 September 2013, 68-69. 
dimensi kebudayaan agama. Adanya pembaharuan penafsiran dan pembongkaran formal-simbolik agama yang mengalami stagnasi tanpa mengubah esensi ajaran agama akan melahirkan apa yang Gus Dur sebut sebagai Islam pribumi. ${ }^{5}$

Pribumisasi Islam di Indonesia merupakan bagian dari upaya dakwah. Namun dalam gagasan Pribumisasi Islam, secara holistik diselaraskan dengan konsep mabadi khoiro ummah (kemaslahatan umat). Pelaksanaan konkretnya adalah menasionalisasikan perjuangan Islam dengan harapan tidak ada lagi kesenjangan antara kepentingan nasional dengan kepentingan Islam. Dakwah Islam perlu diselaraskan atau dipribumisasikan karena menurut Gus Dur, pola amar ma`ruf nahi munkar yang selama ini berjalan lebih banyak berwatak ideologis dan kecenderungan formal-legalistik. Padahal yang dibutuhkan oleh umat Islam Indonesia adalah menyatukan "aspirasi Islam" menjadi "aspirasi nasional". Islam, sebagai salah satu agama yang diakui di Indonesia selain agama-agama yang lain, diaktualisasikan sebagai inspirasi spiritual bagi tingkah laku kehidupan seseorang atau kelompok, dalam bermasyarakat dan bernegara. $^{6}$

Gagasan Islam Nusantara merupakan kelanjutan pribumisasi Islam sebagai ikhtiar pendekatan keagamaan yang tidak melalui struktur legal formal melainkan melalui Islamisasi secara kultural yakni proses dakwah dengan mengakulturasi budaya lokal. Dengan melalui pendekatan budaya ini diharapkan akan mampu menggerakkan perubahan masyarakat (the society aimed movement). Penyebaran Islam ke berbagai wilayah di dunia ini, menyebabkan corak dan varian Islam memiliki kekhasan dan keunikan tersendiri dari pada Islam yang berkembang di Jazirah Arab. Hal ini dapat dipahami karena setiap agama, tak terkecuali Islam, tidak bisa lepas dari realitas di mana ia berada. Islam bukanlah agama yang lahir

${ }^{5}$ Al-Zastrow Ng, Gus Dur: Siapa Sih Sampeyan? Tafsir Teoritik atas Tindakan dan Pernyataan Gus Dur (Jakarta: Penerbit Erlangga, 1999), 266-269.

${ }^{6}$ Zainal Arifin Toha, Kenyelenehan Gus Dur: Gugatan Kaum Muda NU dan Tantangan Kebudayaan ( Yogyakarta: Gama Media, 2001), 206-2. 07 
Arik Dwijayanto, Pribumisasi Islam Nusantara...

dalam ruang yang hampa budaya. Antara Islam dan realitas, meniscayakan adaya dialog yang terus berlangsung secara dinamis. ${ }^{7}$

Kemunculan Islam Nusantara sebagai gerakan keagamaan merupakan upaya menjaga dan mengembangkan keberadaan Islam yang toleran (moderat). Setidaknya ada beberapa faktor yang mendorong pribumisasi Islam Nusantara sebagai suatu gerakan kegamaaan di Indonesia. Pertama, modal historis atas kontribusi santri-kyai melalui resolusi Jihad dalam mempertahankan kemerdekaan telah menguatkan pemahaman bahwa tidak ada dikotomi antara ajaran agama dan nasionalisme. Kedua, sebagai hasil dari internalisasi nilai pendidikan karakter melalui pesantren dan madrasah yang telah terbukti mampu menjadi benteng dalam menghadapi radikalisme keagamaan. Ketiga, sebagai kesinambungan dari eskavasi gagasan-gagasan para pendahulu untuk menghadirkan wajah Islam yang ramah dan Islam yang damai. Keempat, sebagai realisasi dari tanggung jawab organisasi keagamaan yang bertumpu kepada pemahaman ajaran Islam Ahlussunnah waljamaah.

Bila ditelisik lebih jauh, pribumisasi Islam di Indonesia merupakan keniscayaan sejarah. Sejak awal kemunculannya, Islam Nusantara merupakan replikasi model keislaman yang disebarkan Walisongo dan para pengikutnya dengan melakukan transformasi kultural dalam masyarakat. Islam dan tradisi tidak ditempatkan dalam posisi yang berhadap-hadapan, tapi didudukkan dalam kerangka dialog kreatif, di mana diharapkan terjadi transformasi di dalamnya. Proses tranformasi kultural tersebut pada gilirannya menghasilkan perpaduan antara dua entitas: Islam dan budaya lokal. Perpaduan inilah yang melahirkan tradisi-tradisi Islami yang hingga saat ini masih dipraktekkan dalam berbagai komunitas Islam kultural yang ada di Indonesia. ${ }^{8}$

${ }^{7}$ Masnun Thahir, "Pergumulan Hukum Islam dan Budaya Sasak; Mengarifi Fiqih Islam Wetu Telu" dalam Jurnal ISTIQRO', Jurnal Penelitian Islam Indonesia, Volume 06, Nomor 01, 2007, 174

${ }^{8}$ Isnatin Ulfah, "Pergulatan Islam Kultural dan Islam Fundamental Tentang Tradisi Lokal Sebagai Sumber Hukum Islam", Laporan Penelitian Individual, P3M STAIN Ponorogo Tahun 2015, 19. 


\section{Islam Nusantara Sebagai Nalar Beragama}

Dalam kajian filsafat, ontologi keilmuan selalu bersandingan dengan epistemologi, yaitu suatu cabang filsafat yang membicarakan problem sumber pengetahuan, cara memeroleh pengetahuan dan bagaimana pengetahuan tersebut dianggap benar. ${ }^{9}$ Epistemologi dalam bahasa lain disebut dengan istilah "nalar". Melalui nalar, manusia mampu memahami dan mengatur realitas. Namun, nalar hadir tidak dalam ruang kosong. Ia banyak ditentukan berdasarkan kondisi sosial dan dorongan kultural yang mengitari seseorang. Itulah sebabnya, setiap orang dari daerah berbeda memiliki nalar keagamaan yang berbeda. Singkat kata bahwa nalar sebagai aktivitas kesadaran, lahir dan dibentuk dalam konteks sosial yang melingkupinya. ${ }^{10}$

Islam Nusantara sebagai nalar beragama berpijak pada tiga tema besar yakni universalisme Islam, kosmopolitanisme Islam dan Pribumisasi Islam. Ketiga tema ini saling terkait satu sama lain, namun berbeda dari segi wataknya. Dikatakan saling terkait karena ketiganya bersifat deduktif dengan pola piramida terbalik. Dikatakan berbeda watak, karena universalisme Islam berwatak teoritis, kosmopolitanisme berwatak dialogis dan pribumisasi Islam berwatak praksis. Kosmopolitanisme merupakan sikap keterbukaan Islam dalam berdialog dengan peradaban luar, sedangkan pribumisasi Islam adalah bentuk praksis dari keterbukaan tersebut yang terwujud dalam bentuk dialog peradaban Islam dengan peradaban lokal di Indonesia. Istilah yang terakhir inilah yang kemudian masyhur dikenal dengan Islam Nusantara. ${ }^{11}$

\footnotetext{
${ }^{9}$ Jujun S.Suriasumantri, Filsafat Ilmu: Sebuah Pengantar Populer (Jakarta: Sinar Harapan, 1982), 39-59; Hardono Hadi, Epistemologi Filsafat Pengetahuan Kenneth T. Gallagher, Cetakan ke-5 (Yogyakarta: Kanisius, 1999), 13-27.

${ }^{10}$ Bagi al-Jabiri, nalar dibagi dalam dua hal, yaitu; pertama, 'aql al-mukawwin. Akal dalam pengertian ini disebut dengan nalar (akal) murni, sesuatu yang membedakan manusia dengan hewan. Semua manusia memiliki ini. Kedua, 'aql al-mukawwan, yaitu akal yang dibentuk oleh sosio-kultural masyarakat di mana ia hidup. Akal terakhir ini sering disebut dengan nalar budaya. Akal budaya pada keberlanjutannya banyak memengaruhi produksi hukum agama. Lebih lanjut baca Muhammad Abid Al-Jabiri, Takwin Aql al-Arabi, Beirut: Markaz al-Thaqafi alArabi, 1991, 11-13. Pemikiran Jabiri tentang konsepsi nalar banyak diterapkan dalam membaca nalar beragama baik individu maupun institusi, salah satunya Iswahyudi, "MUI dan Dilema Keberagamaan Inklusif”, Laporan Penelitian, P3M STAIN Ponorogo, 81.

${ }^{11}$ Aksin Wijaya, Menusantarakan Islam, (Ponorogo: STAIN Po Press, 2011), 190.
} 
Arik Dwijayanto, Pribumisasi Islam Nusantara...

Islam Nusantara sebagai nalar beragama berupaya untuk berdialektika dengan ajaran-ajaran inti Islam ke dalam budaya-budaya lokal Indonesia dan berusaha untuk selalu mempertimbangkan kebutuhan-kebutuhan lokal masyarakat dalam merumuskan hukum-hukum agama, dengan tanpa mengubah hukumhukum inti agama. Dalam pemahaman Islam Nusantara, ajaran agama tidak untuk menghapus segala yang ada pada manusia dan menolak segala yang datang dari luar. Hal-hal yang sesuai atau sejalan dengan Islam diteruskan (diambil) dan dikembangkan. Hal-hal yang belum sepenuhnya sejalan dengan Islam, diusahakan penyesuaiannya supaya sejalan dengan Islam. Hal-hal yang netral (kosong nilai) diisi dengan nilai-nilai Islam, dan hal-hal yang bertentangan atau tidak mungkin disejalankan dengan Islam, dilarang (dihapus). ${ }^{12}$

Paparan di atas menunjukkan bahwa Islam Nusantara sebagai nalar beragama jelas menempatkan tradisi lokal sebagai suatu landasan bagi sistem interpretasi dalam memahami ajaran agama. Lokalisme itu sendiri, dalam pandangan Islam Nusantara adalah bagian dari kebudayaan Islam. Sedang dari sisi epistemologi, lokalisme memberi suatu pandangan tentang Islam yang dilihatnya sebagai suatu nilai tidak harus terjebak dengan formalisme agama atau konsepkonsep tertentu yang akhirnya membuat Islam itu sendiri menjadi kaku. Lebih dari itu, lokalisme lahir dari kecenderungan pemahaman agama yang melihat kesadaran historis Islam itu sendiri yang sangat lekat dengan budaya lokal. Lokalisme harus dilihat sebagai suatu yang integral dengan agama itu sendiri, dengan tidak mengesampingkan nilai-nilai universalitasnya. Karena dengan cara demikianlah, umat Islam dapat memaknai, memahami, dan mengkontekskan rasa keagamaan dan penghayatan beragama dalam dimensinya yang lain. ${ }^{13}$

Islam Nusantara sebagai nalar beragama kemudian melahirkan moderatisme yang mengakui bahwa al-Qur'an memang menyampaikan putusanputusan spesifik mengenai berbagai persoalan, namun bagi Islam pribumi, tujuantujuan moral dan etis al-Qur'an memainkan peran sentral dan penting dalam proses analisis hukum. Hal ini karena dalam pandangan Islam Nusantara, putusan-

\footnotetext{
${ }^{12}$ Lihat Lukman Hakim, Perlawanan Islam Kultural: Relasi Asosiatif Pertumbuhan Civil Society dan Doktrin Aswaja NU (Surabaya: Pustaka Eureka, 2004), 104.

${ }^{13}$ Wahyudi, Civil Religion, 55.
} 
putusan spesifik dalam al-Qur'an hadir untuk merespon persoalan-persoalan tertentu yang dihadapi umat Islam pada zaman Nabi. Maksud dari putusan spesifik dan khusus yang dinyatakan di dalam al-Qur'an bukanlah tujuan itu sendiri. Putusan-putusan ini bergantung pada lingkungan historis khusus yang bisa ada atau bisa juga tidak ada di era modern. Pada waktu putusan-putusan ini diwahyukan dan dibuat adalah untuk mencapai tujuan moral dari al-Qur'an seperti keadilan, keseimbangan, kesetaraan, kasih sayang, kebajikan dan seterusnya. $^{14}$

Dengan demikian, Islam Nusantara sebagai nalar beragama mempercayai adanya "Islam yang abadi" dengan mempertimbangkan bahwa masa depan dapat membuahkan aktualisasi potensi yang lebih besar ketimbang yang pernah ada di masa silam. Islam Nusantara juga meyakini setiap periode sejarah menyuguhkan sehimpunan tantangannya sendiri yang unik dan harus dihadapi dengan cara mengkajinya dan memberikan perhatian penuh terhadap kebutuhan-kebutuhan masa kini dan pelajaran-pelajaran dari masa silam, sehingga tidak ada alasan apologetic mengidealkan masa silam. Kesalahan-kesalahan di masa silam harus diakui dan dikaji, sementara kesuksesan harus dirayakan tetapi tidak dijadikan idola. Dalam Islam Nusantara, agama adalah kekuatan progresif yang menawarkan kesempatan tiada akhir untuk meraih aktualisasi potensi yang lebih besar di setiap era baru. Aktualisasi potensi itu adalah di mana bagi Islam Nusantara tidak menanggalkan tradisi Islam, tetapi pada saat yang sama juga tidak menolak modernitas sebagai sesuatu yang tidak relevan. Antara tradisi dan modernitas mesti berjalan berkelindan sebagaimana terurai dari pandangan Rahman yang menangkap tradisi dan modernitas sebagai bagian tak terpisahkan, di mana keduanya mesti dikaji secara kritis dan obyektif. Dengan memilah-milah mana yang bermanfaat bagi kemajuan Islam. ${ }^{15}$

Dengan demikian Islam Nusantara adalah wajah gerakan Islam yang bersifat ramah terhadap kearifan lokal. ${ }^{16}$ Gerakan ini memahami nilai

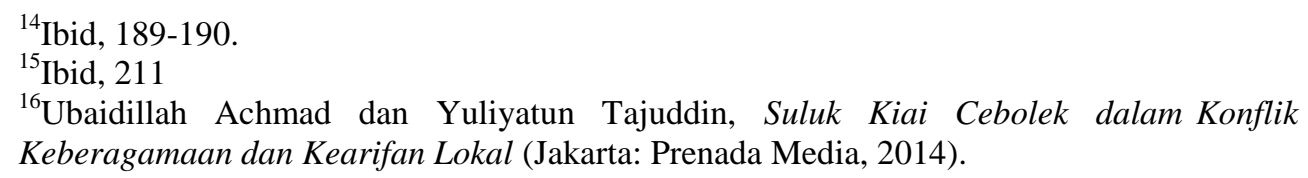


Arik Dwijayanto, Pribumisasi Islam Nusantara...

universalitas sebagai nilai dasar etika kehidupan yang bisa ditemukan pada semua kawasan kehidupan manusia. ${ }^{17}$ Misalnya, di tengah kehidupan modern dan kehidupan masyarakat adat atau lokal, Islam Nusantara berusaha menjaga keamanan ajaran suci agama Islam bebas dari pembajakan kehendak ideologis dan politis. Kerangka berpikir gerakan Islam Islam Nusantara didasarkan pada bangunan risalah kenabian yang selalu tidak terlepas dari pengawasan sistem kehendak kuasa yang hegemonik dan bersikap sewenang-wenang. ${ }^{18}$ Sebagai contoh, nilai universal yang secara berkelanjutan berlangsung dalam kisah kenabian sejak Nabi Dawud, Nabi Yusuf, Nabi Musa, Nabi Isa, hingga Nabi Muhammad berupa ketauhidan, kemanusiaan, keadilan, dan persamaan. Sehubungan dengan perspektif kehendak kuasa yang berpikiran ideologis dan politis, ${ }^{19}$ maka perlu berhati-hati menguatkan peran risalah suci kenabian. Jika tidak hati-hati menerapkan nilai keutamaan, maka akan memunculkan gerakan pembajakan yang akan mengaburkan misi suci risalah kenabian. Bersamaan dengan nilai universal yang diusung oleh para nabi, maka seseorang bisa lebih sederhana dan ramah terhadap lingkungan atau budaya lokal. Model implementasi risalah kenabian ini menjadi prinsip yang terus bertahan melalui regenerasi kenabian melalui perpaduan paradigma universalitas risalah kenabian dan melalui pengakuan para nabi terhadap tradisi-tradisi masyarakat yang sudah menjadi bentuk ajaran kearifan lokal. Allah dan Nabi Muhammad juga selalu mengingatkan, setiap perbuatan tentang kebaikan harus dilakukan dengan kehendak hati dan bukan dengan cara memproklamirkan kebaikan kepada publik. Sudah banyak contoh, kekerasan yang mengatasnamakan agama atau gerakan Islam radikal akan mudah menodai kesucian Islam. ${ }^{20}$

\footnotetext{
${ }^{17}$ H.M. Nasruddin Anshoriy CH, Kearifan Lingkungan dalam Perspektif Budaya Jawa (Jakarta: Yayasan Obor Indonesia, 2008).

${ }^{18}$ Deddy Ismatullah dan Asep A.S. Gatara, Ilmu Negara dalam Multi Perspektif: Kekuasaan, Masyarakat, Hukum, dan Agama (Bandung: Pustaka Setia, 2007), 207.

${ }^{19}$ Firmansyah, Marketing Politik antara Pemahaman dan Realitas (Jakarta: Yayasan Obor Indonesia, 2008), 132.

${ }^{20}$ Ahmad Syafi'i Ma'arif, "Nur Huda Ismail dan Karyanya, Sebuah Pengantar", dalam Nur Huda Ismail, Temanku Teroris: Saat Dua Santri Ngruki Menempuh Jalan yang Berbeda (Jakarta: Penerbit Hikmah, 2010), xi-xii.
} 
Noda ini akan selalu muncul dari orang yang ingin memanfaatkan agama Islam sebagai Islam formalis atau otentik. Fenomena ini disadari oleh para nabi dalam tradisi kenabian, sehingga setiap nabi menunjukkan model keberagamaan yang mempertahankan nilai universalitas, namun juga ramah terhadap kondisi lokal subjek dampingan atau individu dalam sebuah masyarakat. Misalnya, pandangan Nabi Shaleh terhadap hewan unta yang harus dijaga dan tidak boleh disembelih merupakan contoh arti unta pada zaman Nabi Shaleh. Perspektif lokalis Nabi Shaleh berbeda dengan zaman Nabi Muhammad yang menjadikan unta sebagai binatang sembelihan untuk berkurban. Masih banyak contoh praktik lokalitas para nabi yang berbeda-beda yang tidak bersifat simbolik dan formalistik, namun tetap secara berkelanjutan tidak melupakan universalitas keutamaan hidup. Sebagai contoh, penghargaan Nabi Muhammad terhadap kearifan lokal tentang puasa dan tata cara merespons kebersihan serta model pengenalan terhadap agama tauhid. Pernah terjadi kasus pencurian, sementara itu Nabi memerinthkan agar yang telah melakukan pencurian untuk diadili sesuai dengan hukum secara adat. ${ }^{21}$

Dalam konteks keberagamaan abad modern, tidak berbeda dengan zaman tradisi kenabian. Model keberagamaan sekarang ini juga dihadapkan pada tradisi lokal yang membutuhkan penyesuaian dengan nilai universalitas tradisi kenabian. $^{22}$ Adanya fenomena radikalisme agama, karena adanya pemahaman dan sikap yang bersifat atau berbentuk formal yang mengabaikan penghargaan terhadap tradisi lokal. Oleh karena itu, umat beragama Islam secara pemahaman dan perilaku tidak bisa hanya mengacu pada hukum formal atau ajaran formal agama Islam. Sebab, secara formalitas menjalankan agama, seseorang berhadapan dengan tradisi lokal yang bersimetris dengan model keberagamaan anak zaman. Benih-benih radikalisme agama disebabkan oleh keterbatasan menentukan pilihan terhadap model pemahaman dan terhadap sikap

\footnotetext{
${ }^{21}$ Ubaidillah Achmad, "Islam Formalis Versus Islam Lokalis: Studi Pribumisasi Islam Walisongo dan Kiai Ciganjur", Jurnal ADDIN, Vol. 10, No. 1, Februari 2016, 241.

${ }^{22}$ John L. Esposito, Masa Depan Islam, terj. Eva Y. Nukman dan Edi Wahyu (Bandung: Mizan 2010), 112.
} 
Arik Dwijayanto, Pribumisasi Islam Nusantara...

keberagamaan. Imajinasi yang tergambar berupa sikap dan perilaku kekerasan terhadap mereka yang berbeda pilihan. Gejala psikologis model keberagamaan secara formalis ini juga akan menjadi sasaran mereka yang merancang ideologi dan sistem politik melalui sakralitas formalitas agama. Karenanya, Islam Nusantara merupakan Islam yang tidak hanya menganggap penting tradisi lokal, namun juga menganggap berarti sisi manusiawi pihak yang lain atau budaya kecil dari pemikiran pihak lain. Filosofi makna wahyu tidak hanya yang berupa teks secara formal, namun masih banyak lapisan-lapisan kawasan teks kewahyuan yang memerlukan kejian, penelitian, dan penghargaan. Di antara lapisan-lapisan kawasan teks kewahyuan ini ada tradisi kecil yang menjadi fondasi bangunan nilai universal atau tradisi kenabian yang pernah berkembang pada zaman pelaku risalah kenabian. ${ }^{23}$

\section{Islam Nusantara Sebagai Spirit Gerakan Sosial-Keagamaan}

Agama, seperti yang dikemukakan AS Hikam memiliki kemampuan mengkonstruksi sosial, kontra diskursus atau kontra hegemoni terhadap ideologi dan tindakan-tindakan dominan yang ada. Sebagai suatu gerakan keagamaan yang muncul dalam suatu konjungtur sosial dan historis tertentu, gerakan keagamaan sebenarnya bisa dipahami dalam kerangka kontra diskursus dan hegemoni, misalnya terhadap modernisme, kapitalisme, sekularisme, dan isme-isme lainnya. Di sini agama menjadi instrumen konstruk sosial dan kekuatan perubahan sekaligus. $^{24}$

Islam Nusantara tidak muncul dalam ruang hampa. Meskipun pertimbangan keagamaan tetap menempati peran utama, tidak boleh dilewatkan juga realitas dan perkembangan yang ada di luar agama. Oleh karena itu, perlu memahami faktorfaktor sosiologis munculnya praktik-praktik keagamaan. Hal ini dianggap perlu mengingat dinamika Islam Nusantara tidak saja disebabkan oleh dorongan yang terdapat dalam ajaran agama itu sendiri, melainkan juga berkelindan dengan berbagai faktor sosiologis baik yang bersifat makro maupun mikro. Dengan

\footnotetext{
${ }^{23}$ Ubaidillah Achmad, Islam Formalis, 242.

${ }^{24}$ Muhammad AS Hikam, Demokrasi dan Civil Society (Jakarta: LP3ES, 1996), 133.
} 
penjelasan sosiologis, juga diharapkan bisa memahami adanya hubungan yang dialektis antara agama dan realitas sosial yang dapat membentuk dan memicu munculnya Islam Nusantara sebagai gerakan sosial (social movement). Misalnya, ketika adanya wacana FDS (full day school) yang dulu sempat dilontarkan Mendikbud memicu munculnya gerakan penolakan dari berbagai pihak khususnya kelompok yang berada dalam lingkar sekolah berbasis agama atau madrasah. Gerakan penolakan tersebut mendorong lahirnya gerakan sosial melalui beragam ekspresi agar kebijakan FDS (full day school) dibatalkan karena tidak sesuai dengan kultur pendidikan Islam di Indonesia.

Dalam perspektif sosiologi, munculnya Islam Nusantara sebagai spirit gerakan sosial selaras dengan teorinya Neil J. Smelser sebagaimana dikutip oleh Arifin, yang berhasil menemukan beberapa faktor determinan penyebab munculnya gerakan sosial. Dalam pandangan Smelser, faktor-faktor tersebut saling berkelindan dalam memicu terjadinya gerakan sosial. Di antara faktor yang dimaksud adalah ${ }^{25}$ :

Pertama, structural condusivennes. Menurut teori ini, gerakan sosial bermula dari adanya struktur yang mendukung. Krisis multi dimensi yang dihadapi masyarakat menjadi struktur kondusif bagi munculnya gerakan sosial, termasuk gerakan sosio-religi.

Kedua, structural strain. Teori ini menjelaskan bahwa gerakan sosial semakin tidak terbendung apabila struktur kondusif menimbulkan ketegangan struktural. Keterbelakangan yang dialami umat Islam yang semula karena faktor inkonsistensi dengan ajaran Islam semakin parah dengan penetrasi Barat ke dalam dunia Islam untuk menjajah. Dampak kolonialisasi tidak saja membuat umat Islam menderita karena kemiskinan, tapi juga kehilangan identitas mereka karena dominasi Barat tidak hanya dalam bidang ekonomi tapi juga budaya dan ideologi. Dominasi Barat dan dampaknya bagi dunia Muslim tersebut berikutnya menimbulkan ketegangan serius yang mengejawantah dalam berbagai gerakan sosial bahkan gerakan kebangkitan agama.

\footnotetext{
${ }^{25}$ Lihat selengkapnya Arifin, Ideologi dan Praksis Gerakan Sosial Kaum Fundamentalis, 75-76.
} 
Arik Dwijayanto, Pribumisasi Islam Nusantara...

Ketiga, the growth of a generalized belief. Ketegangan struktural menurut Smelser belum begitu mencukupi dalam menghasilkan tindakan kolektif. Agar gerakan sosial bisa diwujudkan diperlukan penjelasan mengenai permasalahan dan solusinya. Dalam konteks ini, interaksi sosial sangat diperlukan untuk saling bertukar pikiran dalam merespon persoalan yang dihadapi bersama.

Keempat, participating factors. Dari segi waktu, gerakan sosial seringkali membutuhkan waktu yang lama. Tetapi gerakan sosial bisa dipercepat jika ada faktor yang mendukungnya. Faktor-faktor itu bisa berupa peristiwa, bisa juga dalam bentuk kehadiran tokoh kharismatik.

Kelima, the mobilization of participant for action. Terjadinya gerakan sosial sangat tergantung juga pada tersediana kelompok yang bisa diorganisasi dan dimobilisasi untuk melakukan tindakan-tindakan tertentu. Pada tahapan ini, pemimpin, komunikasi, dan suplai dana sangat dibutuhkan bagi eksistensi gerakan sosial.

Keenam, operation of social control. Tidak seperti faktor determinan lainnya, Kontrol sosial justru mencegah, menyela, dan menghalangi gerakan sosial. Kontrol ini biasanya dilakukan oleh negara. Ada dua bentuk kontrol terhadap gerakan sosial dan pemerintah. Kontrol pertama berbentuk upaya pencegahan terhadap munculnya tindakan kolektif dengan cara mengurangi faktor pendukung dan ketegangan struktural, seperti melalui peningkatan kesejahteraan. Kontrol kedua dengan cara menekan perilaku kolektif setelah gerakan dimulai seperti mengerahkan petugas keamanan dan menerapkan jam malam. Tetapi tekanan ini tidak selamanya efektif, bahkan banyak kasus menunjukkan, semakin mendapatkan tekanan, semakin mempercepat terjadinya gerakan sosial. ${ }^{26}$

\section{Islam Nusantara dalam Dinamika Keberagamaan di Indonesia}

Islam Nusantara sebagai pemahaman keagamaan berusaha untuk menjadikan agama (Islam) dan budaya lokal tidak saling mengalahkan, melainkan mewujud dalam pola nalar relijiusitas yang tidak lagi mengambil bentuknya yang otentik dan murni (pure) dari agama dan berusaha menjadi jembatan yang selama

\footnotetext{
${ }^{26}$ Ibid.
} 
ini memisahkan antara keduanya (agama dan budaya) ${ }^{27}$. Gagasan tersebut mengejawantah - terutama sekali-didasari oleh keprihatinan terhadap menyebarnya pemahaman Islam yang mengabaikan dan mengebiri dimensi lokalitas dan keragaman kehidupan. Pemahaman Islam dengan corak demikian dikembangkan oleh kalangan -meminjam istilah Fazlur Rahman-revivalisme pra modernis yang tumbuh dan berkembang sejak abad ke $18 \mathrm{M}$ diklaim sebagai respon terhadap degradasi sosio-moral komunitas Muslim yang terjadi saat itu. ${ }^{28}$

Tumbuh suburnya pemahaman Islam ala revivalisme pra modernis ini hingga tahapan tertentu-- telah membuat Islam terputus dari tradisi dan khazanah intelektual Muslim yang sedemikian kaya. Banyak dimensi peradaban dan warisan budaya Islam klasik serta budaya masyarakat yang disikapi secara kaku sebagai sesuatu yang tidak islami. Perspektif demikian, pada gilirannya menggiring kepada upaya pemusnahan -atau minimal pengeluaran-warisan budaya tersebut dari lingkungan keagamaan Islam. Sebagai akibatnya, membuat Islam kurang responsif dalam mensikapi kebutuhan dan persoalan lokal, yang berbeda sekaligus sangat beragam. Pada gilirannya, watak Islam sebagai rahmat li al-'alamin akan kehilangan relevansinya dengan realitas kehidupan yang dialami umat. $^{29}$

Lebih jauh, Islam Nusantara berparadigma bahwa al-Qur'an dan Hadits dikonstruk berdasarkan tradisi yang bersifat partikular dan historis. Bertolak dari optika demikian, bagi paham Islam Nusantara, Islam bukanlah agama yang sekali jadi (instant), Islam tidak lahir dari ruang dan lembaran kosong. Al-Qur'an misalnya — meskipun diyakini sebagai firman Tuhan, pada kenyataannya, kalam Tuhan ini telah memasuki wilayah historis. Dengan mempertimbangkan situasi sosio-historis yang melingkupi firman Allah tersebut, dapat disimpulkan bahwa terdapat hubungan dialektis antara al-Qur'an dan realitas budaya. Persis di dalam sistem budaya yang mendasarinya inilah, al-Qur' an "terkonstruksi” secara kultural dan "terstruktur" secara historis. Hal ini berarti, tidak semua doktrin dan

\footnotetext{
${ }^{27}$ Imdadun Rahmat, "Islam Pribumi: Mencari Wajah Islam Indonesia”, Tashwirul Afkar No. 14 Tahun 2003, 9.

${ }^{28}$ Isnatin Ulfah, Pergulatan Islam Kultural, 35.

${ }^{29}$ Ibid., 36.
} 
Arik Dwijayanto, Pribumisasi Islam Nusantara...

pemahaman agama dapat berlaku sepanjang zaman dan tempat, mengingat gagasan universal Islam telah mengambil lokus bahasa dan budaya Arab yang relatif, berdimensi lokal dan partikular. ${ }^{30}$

Karena sifatnya yang senantiasa berdialektika dengan realitas, maka tradisi keagamaan dapat berubah sesuai dengan konteks sosial dan kultural suatu masyarakat. Atas dasar itu, bagi Islam Nusantara, Islam yang hadir di setiap jengkal bumi ini selalu merupakan produk racikan dialektik antara wahyu dan tradisi, sehingga Islam yang ideal sebagaimana dibayangkan kalangan Islam otentik itu "sebenarnya tidak ada". Yang ada adalah Islam yang riil, yang hidup di tengah masyarakat yang plural ini. ${ }^{31}$

Di hadapan Islam Nusantara, budaya-budaya lokal di mana Nabi terlibat dalam proses konstruksinya memiliki dua keuntungan sekaligus pertama, akan dapat diketahui kepiawaian Nabi dalam membangun pangkalan-pangkalan pendaratan ajaran inti Islam. Dari cara-cara yang dilakukan Nabi itu, dapat diambil pelajaran tatkala hal yang sama hendak dilakukan di bumi sendiri. Kedua, dapa dilakukan penyaringan (seleksi) antara aspek ajaran yang bersifat lokal partikular dan yang bersifat universal. Demikian juga, dapat diidentifikasi ajaran Islam yang fundamental yang terselip atau diselipkan dalam lokalitas. Artinya, Islam Arab harus diperas untuk mendapatkan saripati Islam. ${ }^{32}$

Dengan perspektif demikian, Islam Nusantara sama sekali tidak berpretensi mengangkut budaya-budaya lokal Arab untuk didaratkan di belahan bumi Indonesia, karena menyadari - sepenuhnya-bahwa universalisasi terhadap budaya-budaya lokal Arab seperti itu bukanlah tindakan bijak. Islam Nusantara berusaha mendialektikakan ajaran-ajaran inti Islam ke dalam budaya-budaya lokal Indonesia dan berusaha untuk selalu mempertimbangkan kebutuhan-kebutuhan

${ }^{30}$ Ibid., 37.

${ }^{31}$ Khalil Abdul Karim, Syari'ah: Sejarah Perkelahian Pemaknaan. Ter. Kamran As'ad (Yogyakarta: LKiS, 2003). Bandingkan Fakhruddin Faiz, Hermeneutika al- Qur'an Tema-Tema Kontroversial. (Yogyakarta: Elsaq, 2005), 87-91.

${ }^{32}$ Sudah barang tentu, upaya "pemerasan" dan penyaringan tersebut mesti dilakukan dengan hati-hati agar tidak terperangkap pada upaya purifikasi atau otentifikasi Islam. Periksa Imdadun Rahmat, "Islam Pribumi: Mencari Wajah Islam Indonesia", Tashwirul Afkar. No. 14 Tahun 2003, 19. 
lokal masyarakat dalam merumuskan hukum-hukum agama, dengan tanpa mengubah hukum-hukum inti agama (al-maqasid al-shari'ah). ${ }^{33}$

Lebih tegas lagi, terhadap tradisi lokal yang memberikan jaminan keadilan dan kesejahteraan pada masyarakatnya, Islam Nusantara bertindak sedemikian apresiatif, bahkan tradisi lokal yang yang adiluhung ('urf shahih) dalam perspektif Islam Nusantara memiliki otoritas untuk mentakhsis keumuman sebuah teks, baik al-Qur'an maupun Sunnah. Dengan kerangka pikir demikian, kalangan Islam Nusantara tidak mengumbar vonis negatif apapun terhadap sejumlah keyakinan teologis yang menjadi pegangan masyarakat lokal. Dalam ranah teologis ini, Islam pribumi tidak akan pernah menggantikan posisi Tuhan sebagai Dzat yang paling berhak untuk memberikan "kata putus" di akhirat nanti, sebab Allah sendiri dengan tegas menyatakan "sesungguhnya Tuhanmu yang akan memutuskan di akhirat kelak menyangkut perselisihan yang terjadi diantara mereka [umat manusia])”. Dengan demikian, bagi kalangan Islam Nusantara, agama Islam yang dipeluk oleh masyarakat Jawa, dengan berbagai variasi tradisinya, tidak bisa dipandang sebagai Islam dengan kualifikasi low tradition, sinkretis, sarat bid'ah, mubtadi' dan karena itu tidak sah dan tertolak, tetapi lebih merupakan sebentuk Islam yang diproduksi dari proses kontekstualisasi. ${ }^{34}$

Islam Nusantara yang bernuansa tradisional-kultural sejak kelahirannya berpretensi untuk mentrasformasikan Islam dan mendialogkan antara Islam dengan tradisi lokal. Islam Nusantara di samping disemangati oleh faktor di atas, secara genealogis sesungguhnya mengambil semangat yang telah diajarkan oleh Wali Songo dalam dakwahnya ke wilayah Nusantara sekitar abad ke 15 dan ke 16 di pulau Jawa. Dalam hal ini, Wali Songo telah berhasil memasukkan nilai-nilai lokal dalam Islam yang khas keindonesiaan. Kreativitas Wali Songo ini melahirkan gugusan baru bagi nalar Islam Nusantara yang tidak secara harfiyah meniru Islam di Arab. Tidak ada nalar Arabisasi yang melekat dalam penyebaran Islam awal di Nusantara. ${ }^{35}$

${ }^{33}$ Abdurrahman Wahid, Pergulatan Negara, Agama dan Kebudayaan (Jakarta: Desantara, 2001), 119.

${ }^{34}$ Isnatin Ulfah, Pergulatan Islam Kultural, 40.

${ }^{35}$ Aksin Wijaya, Menusantarakan Islam, 149. 
Arik Dwijayanto, Pribumisasi Islam Nusantara...

Islam Nusantara dengan aksinya tersebut mendapat reaksi dari kelompok Islam lain. Islam Nusantara dituduh sebagai umat Islam yang tidak memahami agama Islam dengan benar dan dianggap penyebab keterbelakangan umat Islam karena fanatik madhab. Sementara upaya Islam Nusantara untuk mendialogkan Islam dan tradisi lokal tersebut menjadi bulan-bulanan pelbagai tuduhan pejorative seperti bid'ah, tahayyul, syirik, dan tidak islami. Tidak hanya tuduhan, Islam Nusantara juga mendapat perlawanan dari kelompok reformis-modernisfundamentalis. Kelompok terakhir ini berusaha keras melakukan purifikasi atas pelbagai aktivitas keagamaan umat Islam yang dianggap sinkretis dan menyerukan "kembali kepada Islam otentik" dengan merujuk langsung kepada alQur'an dan Hadits sebagai sumber ajaran Islam, tanpa bermadhab dan tanpa unsur-unsur budaya. ${ }^{36}$

Dalam perkembangannya, upaya purifikasi tersebut ternyata dilakukan dengan kekerasan dan pemaksaan kehendak. Selain itu, dalam pandangan Islam Nusantara, purifikasi yang dilakukan kelompok fundamentalis merupakan bentuk Arabisasi atau proses mengidentifikasi diri dengan budaya Timur Tengah berarti yang menyebabkan tercerabutnya masyarakat dari akar budayanya. Merespon kondisi tersebut, Islam Nusantara sebagai gerakan keagamaan bereaksi dengan dengan memperjuangkan pribumisasi Islam. Dipelopori para ulama moderat, Islam Nusantara bangkit membela dan menjaga bangunan keagamaan yang berpijak pada tradisi dan institusi madhhab sebagai suatu cara yang sah dalam memahami dan mengamalkan agama. ${ }^{37}$

\section{Penutup}

Dari paparan diatas dapat diambil kesimpulan bahwa Islam Nusantara sebagai gerakan sosial keagamaan merupakan suatu ikhtiar kelompok muslim moderat untuk menjaga dan mengembangkan keberadaan Islam yang membawa rahmat bagi semesta. Menguatnya kelompok muslim moderat dalam melakukan pribumisasi Islam Nusantara sebagai suatu gerakan kegamaaan kultural di

\footnotetext{
${ }^{36}$ Isnatin Ulfah, Pergulatan Islam Kultural, 48.

${ }^{37}$ Abdurrahman Wahid, Pergulatan Negara, Agama, dan Kebudayaan, 13
} 
Indonesia didasari empat faktor. Pertama, modal historis atas kontribusi santrikyai melalui resolusi Jihad dalam mempertahankan kemerdekaan telah menguatkan pemahaman bahwa tidak ada dikotomi antara ajaran agama dan nasionalisme. Kedua, sebagai hasil dari internalisasi nilai pendidikan karakter melalui pesantren dan madrasah yang telah terbukti mampu menjadi benteng dalam menghadapi radikalisme keagamaan. Ketiga, sebagai kesinambungan dari eskavasi gagasan-gagasan para pendahulu untuk menghadirkan wajah Islam yang ramah dan Islam yang damai. Keempat, sebagai realisasi dari tanggung jawab organisasi keagamaan yang bertumpu kepada pemahaman ajaran Islam Ahlussunnah waljamaah.

\section{Referensi}

Abdullah, Abdul Rahman Haji. (1989), Islam dalam Sejarah Asia Tenggara Tradisional, Kuala Lumpur: Penerbitan Pena.

Abdullah, Mudhofir. (2013), "Pribumisasi Islam dalam Konteks Budaya Jawa dan Integrasi Bangsa", Makalah yang disampaikan dalam Dies Natalis XXI IAIN Surakarta.

Achmad, Ubaidillah dan Yuliyatun Tajuddin. (2014), Suluk Kiai Cebolek dalam Konflik Keberagamaan dan Kearifan Lokal, Jakarta: Prenada Media.

Achmad, Ubaidillah (2016), "Islam Formalis Versus Islam Lokalis: Studi Pribumisasi Islam Walisongo dan Kiai Ciganjur”, Jurnal ADDIN, Vol. 10, No. 1, Februari

Anshoriy, Nasruddin. (2008), Kearifan Lingkungan dalam Perspektif Budaya Jawa, Jakarta: Yayasan Obor Indonesia.

Al-Usairy, Ahmad. (2003), Sejarah Islam: Sejak Zaman Nabi Adam Hingga Abad $X X$, Jakarta: Akbar Media.

Al-Zastrow. (1999), Gus Dur: Siapa Sih Sampeyan? Tafsir Teoritik atas Tindakan dan Pernyataan Gus Dur, Jakarta: Penerbit Erlangga.

Azra, Azyumardi. (2007), Jaringan Ulama Timur Tengah dan Kepulauan Nusantara Abad XVII dan XVIII: Melacak Akar-Akar Pembaruan Islam Indonesia, Jakarta: Kencana Prenada Media. 
Arik Dwijayanto, Pribumisasi Islam Nusantara...

Daud, Mustafa Haji (1994), Kesusasteraan Dalam Tamadun Islam, Kuala Lumpur: Utusan Publication Toha, Zainal Arifin. (2001), Kenyelenehan Gus Dur: Gugatan Kaum Muda NU dan Tantangan Kebudayaan, Yogyakarta: Gama Media.

Esposito, John L. (2010), Masa Depan Islam, terj. Eva Y. Nukman dan Edi Wahyu, Bandung: Mizan.

Fadzil, Siddiq. (2000), "Pertembungan Islam dengan Budaya Peribumi: Pengalaman Alam Melayu", Kertas Kerja Seminar Hukum Islam Semasa III, Akademi Pengajian Islam, Universiti Malaya.

Firmansyah. (2008), Marketing Politik antara Pemahaman dan Realitas, Jakarta: Yayasan Obor Indonesia.

Faiz, Fakhruddin. (2005), Hermeneutika al- Qur'an Tema-Tema Kontroversial. Yogyakarta: Elsaq.

Hashim, Muhammad Yusoff. (1988), Pensejarahan Melayu Nusantara, Kuala Lumpur: TP Teks Publishing.

Haji Yahya, Mahayudin. (1998). Islam di Alam Melayu, Kuala Lumpur: Dewan Bahasa dan Pustaka.

Hadi, Hardono. (1999), Epistemologi Filsafat Pengetahuan Kenneth T. Gallagher, Cetakan ke-5 Yogyakarta: Kanisius.

Hakim, Lukman. (2004), Perlawanan Islam Kultural: Relasi Asosiatif Pertumbuhan Civil Society dan Doktrin Aswaja NU, Surabaya: Pustaka Eureka.

Hikam, Muhammad AS. (1996), Demokrasi dan Civil Society, Jakarta: LP3ES. Ismatullah, Deddy dan Asep Gatara. (2007), Ilmu Negara dalam Multi Perspektif: Kekuasaan, Masyarakat, Hukum dan Agama, Bandung: Pustaka Setia.

Iswahyudi. (2015), "MUI dan Dilema Keberagamaan Inklusif”, Laporan Penelitian, P3M STAIN Ponorogo.

Laffan, Michael. (2015), Sejarah Islam di Nusantara, Yogyakarta: Bentang Pustaka 
Machmud, Anas. (1989) "Turun Naiknya Peranan Kerajaan Aceh Darussalam di Pesisir Timur Sumatra", dalam A. Hasymy, Sejarah Masuk dan Berkembangnya Islam di Indonesia, Jakarta: Almaarif.

Ma'arif, Ahmad Syafi'i. (2010), "Nur Huda Ismail dan Karyanya, Sebuah Pengantar", dalam Nur Huda Ismail, Temanku Teroris: Saat Dua Santri Ngruki Menempuh Jalan yang Berbeda, Jakarta: Penerbit Hikmah

Manasikana. (1983), Sastera Islam di Malaysia, Kuala Lumpur: Penerbitan Sarjana Masnun, Thahir. (2007), "Pergumulan Hukum Islam dan Budaya Sasak; Mengarifi Fiqih Islam Wetu Telu" dalam Jurnal ISTIQRO', Jurnal Penelitian Islam Indonesia, Volume 06, Nomor 01.

Microb, Halwany dan Mudjahid Chudari. (1993), Catatan Masa Lalu Banten, Serang: Saudara.

Notosusanto, Nugroho. (1992) Sejarah Nasional Indonesia 2, Jakarta: Depdikbud Pires, Tome. (2014), Suma Oriental: Perjalanan dari Laut Merah ke Cina \& Buku Fransisco Rodrigues, Yogyakarta: Penerbit Ombak.

Ulfah, Isnatin. (2015), "Pergulatan Islam Kultural dan Islam Fundamental Tentang Tradisi Lokal Sebagai Sumber Hukum Islam”, Laporan Penelitian Individual, P3M STAIN Ponorogo .

Sunyoto, Agus. (2012), Atlas Walisongo, Bandung: Mizan.

Suriasumantri, Jujun S. (1982), Filsafat Ilmu: Sebuah Pengantar Populer, Jakarta: Sinar Harapan.

Supriyadi, Dedi. (2008), Sejarah Peradaban Islam, Bandung: Pustaka Setia.

Tjandrasasmita, Uka (1984), Sejarah Nasional Indonesia III, Jakarta: PN Balai Pustaka.

Karim, Khalil Abdul. (2003), Syari'ah: Sejarah Perkelahian Pemaknaan. Ter. Kamran As'ad Yogyakarta: LKIS.

Rahmat, Imdadun. (2003), "Islam Pribumi: Mencari Wajah Islam Indonesia", Tashwirul Afkar. No. 14.

Wahid, Abdurrahman. (2001), Pergulatan Negara, Agama dan Kebudayaan, Jakarta: Desantara. 
Arik Dwijayanto, Pribumisasi Islam Nusantara...

Wijaya, Aksin. (2011), Menusantarakan Islam: Menelusuri Jejak Pergumulan Islam Yang Tak Kunjung Usai, Ponorogo: STAIN Po Press.

Yatim, Badri. (2007), Sejarah Peradaban Islam, Jakarta: Raja Grafindo Press.

Yusuf, Slamet Efendi. (1983), Dinamika Kaum Santri, Jakarta: Rajawali. 